\title{
DO REBRANDING AND RELOCATION AFFECT MARKETING STRATEGY IN CULINARY BUSINESS; A LESSON FROM "KEDAI LOBSTER"
}

\author{
Nada Maharani Wiradarya ${ }^{* 1}$ and Idqan Fahmi ${ }^{*}$ \\ *) School of Business, IPB University \\ Jl. Pajajaran, Bogor 16151
}

\begin{abstract}
Since Kedai Lobster did a rebranding and relocation, sales has been decreasing. Are there any relation between rebranding and relocation with sales decrease and how to increase the sales volume is the problem that will be investigated. This research was conducted with the aim to: analyse respondents assessment of the importance level of restaurant marketing mix attributes in general, analyse the level of performance of the Kedai Lobster marketing mix and formulate marketing strategy for Kedai Lobster. This research will be analysed using descriptive analysis and Importance Performance Analysis (IPA). Based on the results of the IPA diagram, strategies that can be formulated are adjusting the product price with the portion, stocking the ingredients, creating Kedai Lobster neon box, increasing the quality and intensity of social media promotions, replacing the restaurant lighting, adding air conditioners, and providing music (non live).
\end{abstract}

Keywords: marketing mix, IPA, rebranding, relocation, marketing strategy

Abstrak: Sejak Kedai Lobster melakukan rebranding dan relocation, mulai terjadi penurunan penjualan pada restoran. Apakah ada hubungan antara rebranding dan relocation dengan penurunan penjualan serta bagaimana cara meningkatkan kembali volume penjualan merupakan masalah yang akan diteliti. Penelitian ini dilakukan dengan tujuan menganalisis penilaian responden terhadap tingkat kepentingan atribut bauran pemasaran restoran secara umum, menganalisis tingkat kinerja bauran pemasaran Kedai Lobster dan menyusun rancangan strategi pemasaran bagi Kedai Lobster. Penelitian ini akan dianalisis menggunakan analisis deskriptif dan Importance Performance Analysis (IPA). Berdasarkan hasil diagram IPA keseluruhan didapatkan rumusan strategi pemasaran bagi Kedai Lobster yaitu menyesuaikan harga produk dengan porsi, melengkapi persediaan bahan baku, membuat neon box Kedai Lobster, meningkatkan kualitas dan intensitas promosi social media, mengganti penerangan lampu restoran, menambah mesin pendingin ruangan, dan menyediakan alunan musik lagu (non live).

Kata kunci: bauran pemasaran, IPA, rebranding, relocation, strategi pemasaran

\footnotetext{
${ }^{1}$ Corresponding author:

Email: maharani.nada@yahoo.com
} 


\section{INTRODUCTION}

Bogor is one of many potential cities for economic development and growth due to its strategic location and it ranks 19th for highest population in West Java with 1.081.009 (BPS, 2019). Due to the economic potential in Bogor, many businessmen are interested in opening their business there, where usually its a restaurant. Various apparent opportunities increased the number of restaurant business in Bogor, as shown in Table 1.

Table 1. Increase in number of restaurants in Bogor from 2013 to 2017

\begin{tabular}{ccc}
\hline Year & Number of restaurant business & Increase (\%) \\
\hline 2013 & 391 & - \\
2014 & 512 & $23,63 \%$ \\
2015 & 633 & $19.11 \%$ \\
2016 & 784 & $19.26 \%$ \\
2017 & 810 & $3,21 \%$ \\
\hline
\end{tabular}

Source: Bappeda (2018)

The accelerating increase of number of restaurants as shown in Table 1 becomes a challenge for businessmen due to the increasing competition. Furthermore, development in technology makes it easier for customer to access information about a product, therefore customer becomes more selective in choosing products they will consume (Putri et al. 2018). This creates a new challenge for a business owner as they need to prepare a strategy to make sure that their product will be chosen by customers.

One of the restaurants that are struggling with competitiveness in the restaurant business in Bogor is Kedai Lobster. Kedai Lobster is a restaurant that mainly offers various types of lobsters. In the midst of harsh restaurant business competition, Kedai Lobster made two changes, which are restaurant rebranding and relocation. After changing its name to Kedai Lobster and changing its location to Pandu Raya, the sales decreased compared to when it was still located in Binamarga with the name of Waroeng Lobster. The comparison can be seen in Figure 1.

To find the connection between rebranding and relocation with the decrease in revenue and to increase its sales volume, a strategy is needed, based on the evaluation on marketing mix. According to Refaldi (2018), the marketing strategy that has an important role in determining the product sales level is marketing mix. Therefore, performing a respondent assessment on marketing mix is expected to help Kedai Lobster found out their lack of performance that should be improve in order to make a positive impact in its sales.

\section{METHODS}

This research uses two data types, primary and secondary data. Primary data is data collected from interview with the owner, direct observation and questionnaire distribution to respondent. Questionnaire is distributed through convenience sampling method, where every respondent who meets the requirements is chosen based on the availability of customers around the location of the research (Umar, 2005).

The respondents in this do not only consist of customer, but also non customers. Customer and non-customer chosen as respondents are those who meet the criteria such as aged above 16 years old, because customer aged above 16 years have entered the teenager phase have a mature mind required in making a decision (Sumarwan, 2004).

The size of the sample that will be used refers to Bailey (1978) which states that a research that uses an analysis of statistical data requires minimal sample size of 30 . Therefore, in this research the number of respondents used is 80 people, consisting of 40 customer respondents and 40 non-customer respondents.

Secondary data used in this research is literature study, literature related to the problems that become the focus of this research and company's documents related to the researched problems. The collected data will be processed and analyzed with descriptive analysis and Importance Performance Analysis (IPA).

Descriptive analysis is used to illustrate the attributes of marketing mix (7P) that have been performed by Kedai Lobster after its rebranding and relocation and to describe the characteristics of Kedai Lobster respondents. Meanwhile, Importance Performance Analysis (IPA) is used to measure the importance and performance of attributes in marketing program, therefore improving the development of effective marketing program. 
Importance Performance Analysis (IPA) was proposed and introduced for the first time by Martilla and James (1997), that consists of coordinate plane where y-axis is importance and $\mathrm{x}$-axis is performance from various service elements, as shown in Figure 2

The interpretation from Importance Performance Analysis (IPA) Grid as shown in Figure 2 will be categorized in four quadrants (Silva and Fernandes, 2011): Concentrate here (The importance level of attributes in this quadrant is above the average, but the performance level of the attributes is below the average. This indicates that those attributes need immediate attention for improvements because those are the main weakness of the company); Keep up the good work (The importance level and performance level of attributes in this quadrant is above the average. Those attributes indicate the opportunity to achieve

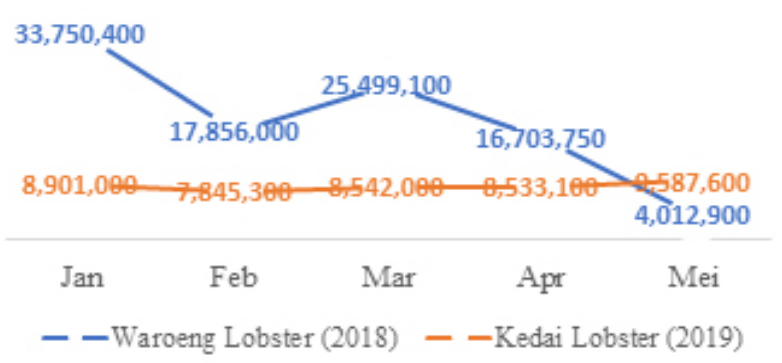

Figure 1. Comaparison of sales data for Waroeng Lobster in 2018 and Kedai Lobster in 2019 or maintain the competitive quality because those are the main strength of the company); Low priority (The importance level and performance level of attributes in this quadrant is below the average. This shows a small weakness in the company, but does not need extra effort because those attributes are not considered much important by the customer or user); Possible overkill (The importance level of attributes in this quadrant is below the average, but the performance level is above the average. This indicates the resource used in those attributes is too much, therefore those resource can be used on another attribute).

In this research, the attributes in quadrant $\mathrm{A}$ (concentrate here) will be made as material for the creation of marketing strategy for Kedai Lobster. Schematically, the framework is illustrated in Figure 3.

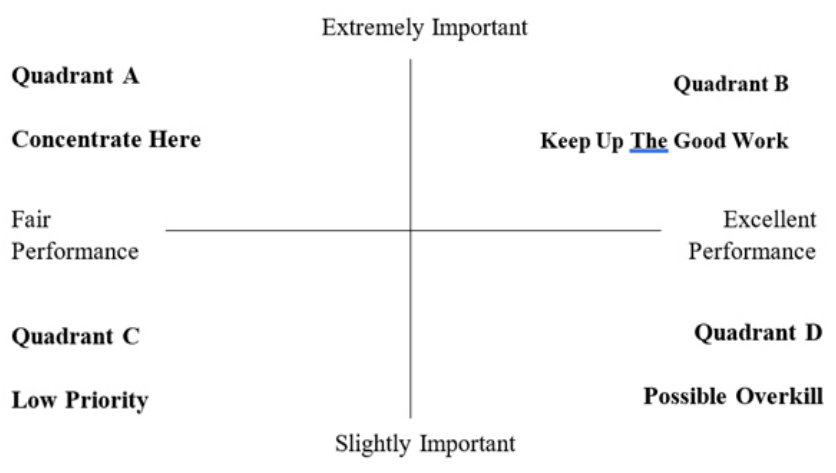

Figure 2. Importance Performance Analysis (IPA) Grid (Martilla and James, 1977)

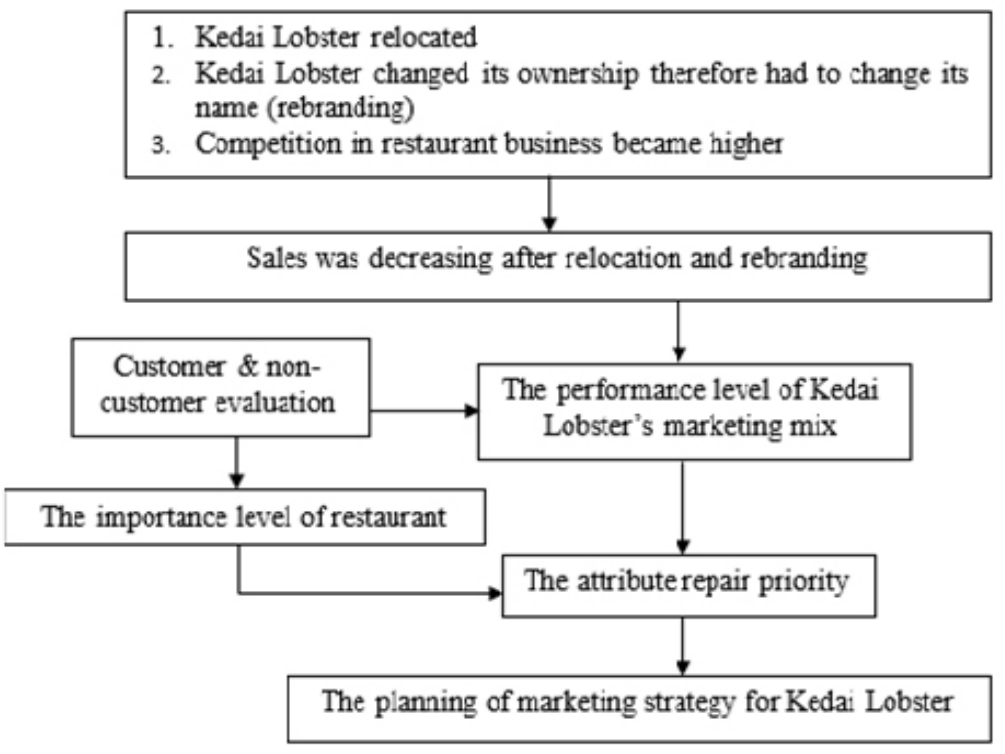

Figure 3. The research framework 


\section{RESULTS}

\section{The Importance Level of Restaurant Attributes and Performance of Kedai Lobster}

In this research, respondent will rate the importance level of marketing mix attribute generally and the performance level of Kedai Lobster after its rebranding and relocation. The purpose of the evaluation on importance level of restaurant attribute is to know the importance of the tested restaurant attribute for the respondents. Meanwhile, the purpose of the evaluation on the performance level of Kedai Lobster is to know if there is a connection between rebranding and relocation and the sales decrease and to know the performance of Kedai Lobster's marketing mix that should be repaired. The result of respondents' evaluation are presented in Table 2.

Based on the results in Table 2, it can be seen that the importance and performance level of the attribute "the brand visually and verbally attractive" are below the average according to customer. On the other hand, according to customer, two other attributes, which are "the brand is memorable" and "the brand logo is readable" have importance and performance level of above the average.

Based on evaluation from non-customers, the attribute "the brand is memorable" has above average importance and performance level, meanwhile the attribute "the brand visually and verbally attractive" has below average importance and performance level. The attribute "the brand is readable" is considered to have above average performance level but has below average importance level.

Based on the results of the evaluation performed by customer and non-customer, it is strongly suspected that rebranding didn't cause any problem to restaurant. This is shown by the absence of brand attribute that has below average performance level but above average importance level. This indicates that there are no brand attributes that need to be fixed immediately. Therefore, if sales keep decreasing, it might be caused by another factor.
For location attributes, it can be seen that according to the customer, convenient location attribute has below average importance and performance level. Good visibility, easy access and curb side appeal have above average importance and performance. However, customers consider the last attribute, parking area, as above average on the importance level but below the average on the performance level.

Next, when observed from the evaluation by noncustomers, the attributes easy access and curb side appeal have above average importance and performance level. Meanwhile, the other three attributes, which are good visibility, convenience and parking area are considered to have below average importance and performance level.

Based on the result of the evaluation, it can be concluded that relocation did not cause any problem for the restaurant. This is because it is only one of five attributes that needs to be fixed in its performance according to customers. Meanwhile, according to the evaluation from non-customers, there is no location attributes that needs to be fixed immediately in its performance. Therefore, fixing the performance on one of the location attributes, which is parking area, won't significantly affect the sales increase. This is because according to customer and non-customer there are other attributes which are considered more urgent and needs to be improved to increase sales.

When observed from the analysis of brand and location attributes above, it can be concluded that rebranding and relocation are not the main reason of the restaurant's sales decline. Therefore, it is not a problem for new business such as Kedai Lobster to rebrand and relocate. However, if the sales decrease is still happening after the rebranding and relocation, it is more likely caused by another factor. Therefore, the discussion of performance improvement will only focus on the attributes inside quadrant $\mathrm{A}$ and that will become the main priority for performance improvements. 
Table 2. The evaluation of importance level of restaurant attributes and performance of Kedai Lobster

\begin{tabular}{|c|c|c|c|c|c|c|c|}
\hline \multirow{2}{*}{ Code } & \multirow{2}{*}{ Atribute } & \multicolumn{2}{|c|}{ customers } & \multicolumn{2}{|c|}{ non-customers } & \multicolumn{2}{|c|}{ Both } \\
\hline & & $\mathrm{X}$ & $\mathrm{Y}$ & $\mathrm{X}$ & $\mathrm{Y}$ & $\mathrm{X}$ & $\mathrm{Y}$ \\
\hline P1.1 & Food taste & 4.50 & 4.70 & 3.68 & 4.70 & 4.21 & 4.70 \\
\hline $\mathrm{P} 1.2$ & Beverage taste & 4.35 & 4.48 & 3.68 & 4.55 & 4.11 & 4.51 \\
\hline P1.3 & Food portion & 2.80 & 4.65 & 3.71 & 4.58 & 3.04 & 4.61 \\
\hline P1.4 & Beverage portion & 4.10 & 4.70 & 3.69 & 4.50 & 4.00 & 4.60 \\
\hline P1.5 & Variety menu & 3.10 & 4.70 & 3.19 & 4.10 & 3.13 & 4.40 \\
\hline P1.6 & Ingredient freshness (seafood) & 4.63 & 4.65 & 4.17 & 4.63 & 4.52 & 4.64 \\
\hline P1.7 & Menu availability & 2.95 & 4.75 & 3.77 & 4.58 & 3.15 & 4.66 \\
\hline P1.8 & The brand is memorable & 3.90 & 4.65 & 4.13 & 4.53 & 4.01 & 4.59 \\
\hline P1.9 & The brand visually and verbally attractive & 3.35 & 4.10 & 3.43 & 4.08 & 3.39 & 4.09 \\
\hline $\mathrm{P} 1.10$ & The brand logo is readable & 4.00 & 4.50 & 4.23 & 4.00 & 4.11 & 4.25 \\
\hline $\mathrm{P} 2.1$ & Good visibility & 3.75 & 4.68 & 3.33 & 4.15 & 3.54 & 4.41 \\
\hline P2.2 & Easy access & 4.23 & 4.60 & 3.90 & 4.58 & 4.06 & 4.59 \\
\hline P2.3 & Convenience & 2.88 & 4.15 & 3.20 & 4.20 & 3.04 & 4.18 \\
\hline P2.4 & Curb side appeal & 4.70 & 4.68 & 4.28 & 4.48 & 4.49 & 4.58 \\
\hline $\mathrm{P} 2.5$ & Parking area & 2.65 & 4.55 & 3.03 & 4.13 & 2.84 & 4.34 \\
\hline P3 & Price and product suitability & 2.70 & 4.70 & 3.69 & 4.63 & 2.98 & 4.66 \\
\hline P4.1 & Waitress alertness in serving the customer & 3.00 & 3.70 & 3.85 & 4.50 & 3.21 & 4.10 \\
\hline $\mathrm{P} 4.2$ & Waitress hospitality & 4.55 & 4.10 & 4.06 & 4.50 & 4.41 & 4.30 \\
\hline P4.3 & Waitress knowledge about the product & 3.23 & 4.00 & 3.87 & 4.48 & 3.40 & 4.24 \\
\hline P5.1 & Speed of serving & 4.40 & 4.80 & 3.88 & 4.60 & 4.25 & 4.70 \\
\hline P5.2 & Speed of payment transaction & 4.68 & 4.55 & 3.87 & 4.58 & 4.45 & 4.56 \\
\hline P5.3 & The alertness of restaurant in responding to complaint & 3.10 & 3.80 & 4.00 & 4.50 & 3.32 & 4.15 \\
\hline P6.1 & $\begin{array}{l}\text { Publishing new name and location through social } \\
\text { media }\end{array}$ & 2.75 & 3.90 & 3.38 & 4.55 & 3.06 & 4.23 \\
\hline P6.2 & Endorsement through Instagram & 2.60 & 4.00 & 3.15 & 4.68 & 2.88 & 4.34 \\
\hline P6.3 & $\begin{array}{l}\text { Register the restaurant location and name to Google } \\
\text { My Business }\end{array}$ & 4.58 & 4.70 & 3.93 & 4.60 & 4.25 & 4.65 \\
\hline P6.4 & Register the restaurant location and name to Zomato & 4.30 & 4.70 & 3.50 & 4.63 & 3.90 & 4.65 \\
\hline P6.5 & Promotion through social media & 3.70 & 4.60 & 3.25 & 4.65 & 3.48 & 4.63 \\
\hline P6.6 & Restaurant name board visibility & 3.00 & 4.60 & 3.20 & 4.68 & 3.10 & 4.64 \\
\hline P7.1 & Restaurant lightning & 3.80 & 4.55 & 3.10 & 4.60 & 3.45 & 4.58 \\
\hline P7.2 & Temperature inside the restaurant & 3.20 & 4.65 & 3.75 & 4.50 & 3.43 & 4.55 \\
\hline P7.3 & Toilet cleanliness & 4.50 & 4.50 & 3.73 & 4.53 & 4.33 & 4.51 \\
\hline P7.4 & Restaurant decoration & 4.10 & 4.60 & 3.21 & 4.58 & 3.70 & 4.59 \\
\hline P7.5 & Praying room cleanliness & 2.90 & 3.85 & 3.92 & 4.50 & 3.13 & 4.18 \\
\hline P7.6 & Hours of operation & 4.30 & 4.00 & 3.85 & 3.80 & 4.08 & 3.90 \\
\hline \multirow[t]{3}{*}{ P7.7 } & Music (non live) & 2.03 & 4.50 & 3.77 & 4.53 & 2.45 & 4.51 \\
\hline & Average Total & 127.28 & 155.28 & 128.33 & 156.30 & 126.90 & 155.79 \\
\hline & Average Value & 3.64 & 4.44 & 3.67 & 4.47 & 3.63 & 4.45 \\
\hline
\end{tabular}

Notes: P1 (Product); P2 (Place); P3 (Price); P4 (People); P5 (Process); P6 (Promotion); P7 (Physical evidence); X (Performance Value); Y (Importance Value). 


\section{Managerial Implications}

Marketing strategy is designed based on the integration of the evaluation from customers and non-customers on the marketing mix of Kedai Lobster. It is designed to get a well-integrated strategy for customers and non-customers. Therefore, the IPA cartesian diagram that will be used for strategy preparation is the comprehensive IPA cartesian diagram, which includes the incorporation of the priority of attributes that should be fixed in their performance according to customers and non-customers. The result of comprehensive IPA cartesian diagram is presented in Figure 4.
Out of eight priority attributes inside the quadrant A, non-customers give higher rating to six attributes, meanwhile customers give higher rating only to two attributes. The gap between the non-customer and customer ratings can be the source for marketing strategy preparation, which is carried out by increasing the performance of priority attributes. This strategy is created to attract customers to come back to the restaurant and maintain the high expectations of the non-customers to restaurant.

There are seven strategies created from eight attribute priorities. The description of every strategy will be listed based on its importance level to make it easier for Kedai Lobster to choose the best strategy that should be implemented first. Here are the descriptions of the seven marketing strategies for Kedai Lobster:

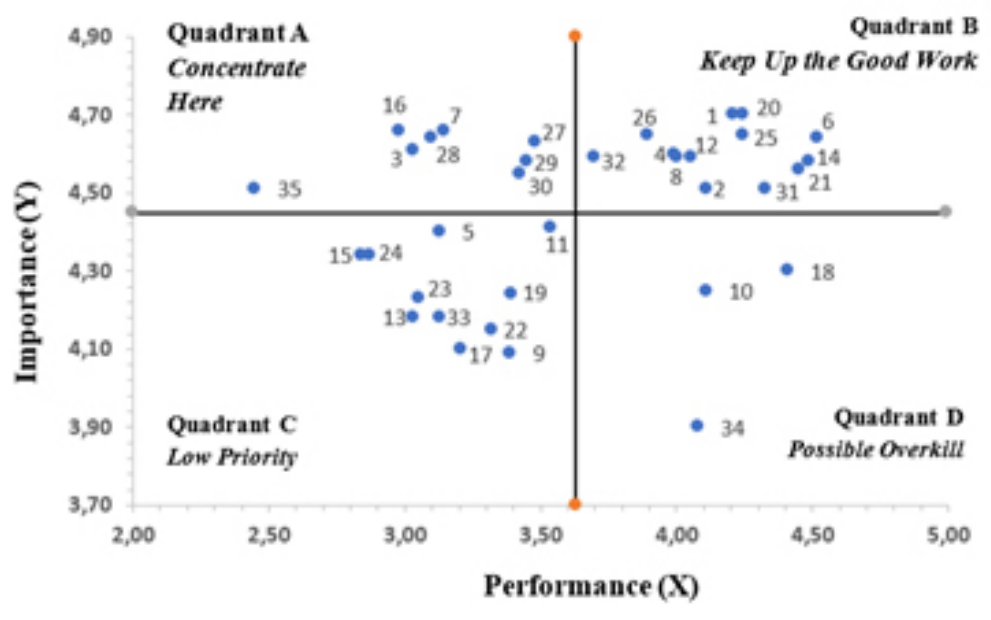

Description:

\section{Quadrant A}

(3) Food portion (P1)

(7) Menu availability (P1)

(16) Price and product suitability (P3)

(27) Promotion through social media (P6)

(28) Restaurant name board visibility (P6)

(29) Restaurant lightning (P7)

(30) Temperature inside the restaurant (P7)

(35) Music (non live) (P7)

\section{Quadrant B}

(1) Food taste (P1)

(2) Beverage taste (P1)

(4) Beverage portion (P1)

(6) Ingredient freshness (seafood) (P1)

(8) The brand is memorable (P1)

(12) Easy access (P2)

(14) Curb side appeal) (P2)

(20) Speed of serving (P5)

(21) Speed of payment transaction (P5)

(25) Register the restaurant location and name to Google My Business (P6)

(26) Register the restaurant location and name to Zomato (P6)

(31) Toilet cleanliness (P7)

(32) Restaurant decoration (P7)

\section{Quadrant C}

(5) Variety menu (P1)

(9) The brand visually and verbally attractive (P1)

(11) Good visibility (P2)

(13) Convenience (P2)

(15) Parking area (P2)

(17) Waitress alertness in serving the customer (P4)

(19) Waitress knowledge about the product (P4)

(22) The alertness of restaurant in responding to complaint (P5)

(23) Publishing new name and location through social media (P6)

(24) Endorsement through Instagram (P6)

(33) Praying room cleanliness alat (P7)

Figure 4. Comprehensive IPA cartesian diagram 
Adjusting the product price with the portion

This strategy is created based on the incorporation of two quadrant A attributes, food portion and the suitability of price and product. Those two attributes are incorporated to produce interrelated strategy. The suitability of price and produce attribute has the highest importance level of 4.66 than the other eight attributes, meanwhile food portion has importance level of 4.61. To improve those two attributes, restaurant owner can review the prices that are adjusted with the given portion. Price and portion can also be adjusted by seeing the characteristics of respondent majority of Kedai Lobster.

\section{Stocking the ingredients}

This strategy is created based on one of the product attributes, menu availability. This attribute has second highest importance level, with value of 4.66. Based on questionnaire results, respondents thought that the performance of menu availability of Kedai Lobster is still below average, meanwhile its importance level is above average. This shows that the most of the menu in Kedai Lobster is often not available. Therefore, the strategy of stocking the ingredients is created so that every menu item offered is always available. However, because lobster is a commodity that is difficult to get, one of the ways to get easier access to lobster is by cooperating with lobster supplier. By this collaboration, not only does it facilitate an easier access to ingredients, but also it might decrease the price of ingredients.

\section{Creating Kedai Lobster neon box}

This strategy is based on the restaurant name board visibility attribute; whose performance is still below average. Name board visibility attribute has third highest importance level, which value of 4.64. The name board that Kedai Lobster currently has in the form of banners, hanged in front of restaurant. There is no guide name board visible on the side of the road. This causes confusion for customers who want to find the location of Kedai Lobster and will pass the restaurant. To solve this problem, management can add Kedai Lobster neon box to facilitate the customer and non-customer in finding the location of the restaurant during morning or evening.
Increasing the quality and intensity of social media promotion

This strategy is created based on promotion through socialmediaattribute. This attributehas the fourth highest importance level, with value of 4.63 . The presence of this attribute in quadrant $A$ shows that the performance of Kedai Lobster's social media is still below average, according to respondent. There are several ways to increase the quality of social media, such as by hiring a graphic designer to design templates that can be used on every post on Instagram or hiring a video editor to create promotional videos. Kedai Lobster can also maximize its promotion through Instagram by adding uploaded content variation, such as promotion video or fun facts related to lobsters. Furthermore, to strengthen the connection with the customers, Kedai Lobster can be more active in interacting with the customers through snapgram feature, such as hosting quiz or polls related to Kedai Lobster. The intensity of contain upload can also be increased to keep the customers updated about Kedai Lobster. The increase of Instagram promotion is expected to attract non customers to visit and customers to revisit Kedai Lobster.

\section{Replacing the restaurant lighting}

This strategy is based on the restaurant lighting attribute which has an importance level of 4.58 and has below average performance level. This result shows that the lighting in the restaurant is still not bright enough for the respondents. Therefore, to improve the performance of this attribute, the restaurant management can replace the restaurant lighting with other lamps of higher wattage or change the color of the lamps to white so that there is brighter lightning in the restaurant. Improving the restaurant lightning is expected to attract customers and non-customers to visit.

\section{Adding air conditioner}

This strategy is created based on the attribute of temperature in restaurant. This attribute has importance level of 4.55. The presence of this attribute in this quadrant shows that the temperature inside the restaurant is not cool enough for the respondents. Therefore, restaurant management can add more air conditioners or fans to make the temperature of the restaurant cooler and more comfortable. 
Providing music (non live)

Unlike the other attributes, this attribute has not been implemented yet by Kedai Lobster. However, this attribute shows up based on the suggestions given by customers on the initial phase of problem searching interview. Therefore, this attribute is inserted on the questionnaire and evaluated by respondents. Based on the results of questionnaire, respondents believe this attribute should be added because its importance value is above the average, which is 4.51 . Based on this result, restaurant management could add non live music to liven up the ambiance in the restaurant.

Furthermoe, employees have trust to the leader as they believe that their leader always base on the established regulation, instead of subjective judgment. In conclusion, the leader's behaviour and the leader's commitment on the fair treatment are subjects to create ethical climate in organizations.

\section{CONCLUSIONS AND RECOMMENDATIONS}

\section{Conclusions}

Based on the evaluation on the importance level of restaurant attributes and performance level of marketing mix of Kedai Lobster, rebranding and relocation are not the main cause of restaurant's sales decline. Therefore, it is not a problem for new business such as Kedai Lobster to rebrand and relocate. However, if the sales of the restaurant keep decreasing after rebranding and relocation, the decrease might be caused by another factor. The market strategy is designed based on the result of questionnaire analyzed with Importance Performance Analysis (IPA). The order in which marketing strategies should by implemented by Kedai Lobster is: adjusting the product price with the portion, stocking the ingredients, creating Kedai Lobster neon box, increasing the quality and intensity of social media promotion, replacing the restaurant lighting, adding air conditioner, providing music (non live).

\section{Recommendations}

Based on the conducted research, the researchers suggest that the next research should analyze the customer satisfaction after Kedai Lobster implementing the marketing strategy created from this research. The next research also can analyze the external factor in micro through Five Forces Porter (customer, suppliers, potential entrants, substitute products, degree of rivalry) to see the effect of an external factor against the sales decreasing in Kedai Lobster.

\section{REFERENCES}

[Bapenda] Badan Pendapatan Daerah. 2018. Perkembangan Jumlah Restoran di Kota Bogor 2013-2017. Bogor: Dispenda Kota Bogor.

[BPS] Badan Pusat Statistika Jawa Barat. 2019. Proyeksi penduduk menurut Kabupaten/Kota di Jawa Barat, 2010-2018. jabar.bps.go.id. http:// bit.ly/3799ujq.[internet]. [2019 Nov 30].

Putri FA, Sumartias S, Sjoraida DF. 2018. Proses rebranding Mal Grand Indonesia oleh departemen marketing communication PT Grand Indonesia. Jurnal Ilmiah Ilmu Hubungan Masyarakat 2(2): 102-118.

Refaldi B. 2018. Analisis pengaruh bauran pemasaran dalam meningkatkan volume penjualan di Kedai Ayam Geprek Abang Ireng di Dramaga Bogor [skripsi]. Bogor: Institut Pertanian Bogor.

Umar H. 2005. Riset Pemasaran \& Perilaku Konsumen. Jakarta: PT Gramedia Pustaka Utama.

Sumarwan U. 2004. Perilaku Konsumen Teori dan Penerapannya dalam Pemasaran. Bogor: Ghalia Indonesia.

Bailey KD. 1978. Methods of Social Research. New York: Free Press.

Martilla JA, James JC. 1977. Importance performance analysis an easily-applied technique for measuring attribut and performance can further the development of effective marketing programs. Journal of Marketing 41(1): 77-79.

Silva FJH, Fernandes PO. 2011. ImportancePerformance Analysis as A Tool in Evaluating Higher Education Service Quality: The Empirical Results of Estig (IPB). Creating Global Competitive Economies: A 360-Degree Approach. 17th IBIMA Conference; 2011 November 14-15; Milan, Italy. Milan (ITA): IBMA Publishing. Hlm 306-315. 